\title{
Leadership Wisdom: from the annals of History
}

\author{
Komaldeep Kaur \\ School of Commerce \& Management, GSSDGS Khalsa College, Patiala
}

\begin{abstract}
Using history to teach important business concepts such as having a vision, strategic thinking, problem solving, effective communication and team building can make these concepts not only much more accessible and comprehensible, but also interesting, relevant and memorable. Renowned writer Robbin Sharma considers the concept of leadership begins within, by having the self discipline to lead \& know oneself. It will not be wrong to say that in order to go ahead it is important to look back. It is more necessary than ever before to tap the wisdom \& experience of some of history's greatest leaders. They may be long gone however their unique achievements still stand \& today's executives can gain valuable insight \& direction from them. Leadership lessons from the past masters can be useful in handling the high-tech \& fast changing world.
\end{abstract}

Keywords: Values, communication, courage, history, experience

\section{Introduction}

History is filled with the achievements of great leaders \& in order to frame futuristic leadership skills, an organization may bask in the glory of historical figures whose leadership skills have stood the test of time. Indeed, the past is a goldmine of wisdom waiting to be explored. Leadership has been defined as a process through which a person influences and motivates others to get involved in accomplishment of a particular task. This single definition, although universally accepted, fails to define the particular paths and ways of people who are deemed as great leaders. All great leaders had something unique about them and yet they were bound by greatness that helped them to lead masses to innovation and new ideologies.

Since the oldest times known to men, masses have been led by efficient leaders. Such men and women have been responsible for ushering their people into a new and more modern world as we know of it now. Although times have changed, the contributions of these great leaders cannot be forgotten and although practices and ways of doing things have changed as well, the ways of these great leaders cannot be overlooked. What made them great might still be applicable in today's day and age \& whether one is a manager or part of a team at work, history's great leaders still provide lessons for us all.

\section{Alexander The Great - Live Your Values}

Remember upon the conduct of each depends the fate of all.

-Alexander the Great

Alexander III of Macedon, commonly known as Alexander the Great, was the creator of one of the largest empires in ancient history, stretching from the Ionian Sea to the Himalaya. He was undefeated in battle and is considered one of the most successful commanders of all time. Conqueror and King of Macedonia, Alexander the Great was born July 20, 356 B.C. in Pella, Macedonia. During his leadership, he united the Greek city-states and led the Corinthian League. He also became the king of Persia, Babylon and Asia, and created Macedonian colonies in Iran. While considering the conquests of Carthage and Rome, Alexander died of malaria in Babylon on June 13, 323 B.C.

One night at Gaugamela, the armies of Alexander and Darius, King of Persia, came in sight of each other. The noise and campfires of the vast barbarian camp were so frightening that some of Alexander's generals advised a night attack because it would be too dangerous to take on such a huge force in daylight. But Alexander replied: "I will not steal victory." Living by one's values helps building relationships \& cultivating loyalty. And it is a universal truth that respect rather than fear will yield the desired commitment from the team \& leadership is actually a philosophy for life. Alexander's success as a leader can be attributed to his ever ending \& undisputed manner of following \& exemplifying his values.

\section{Abraham Lincoln-Patience, Perseverance \& Never Give Up}

\section{"Give me six hours to chop down a tree and I will spend the first four sharpening the axe." -Abraham Lincoln}

Abraham Lincoln was born in a one-room log cabin in Kentucky in 1809. He educated himself from borrowed books, studying at the end of each day's labours on the farm. He went on to teach himself law, passed his bar examination and became involved in politics. In 1856 he joined the Republican party, recently founded on an anti-slavery platform. He became the first Republican president of the United States in 1860. 
The issue of slavery threatened to split the country in two \& the America civil war was about to begin. When Lincoln started his presidency he was desperate merely to hold the United States together. The new nation's radical experiment in republican government was in danger of fragmenting into a collection of loosely associated states; of ceasing to be a nation. Lincoln had two primary strategic goals: (1) ending slavery; and, (2) ending the war. Over and over, he was tempted to take shortcuts that would have accomplished one goal but would have left the other in peril. He refused to compromise on either front, weathered the storm, and ultimately achieved what most thought was impossible.

Lincoln success as a leader can also be attributed to his attitude of never giving up even in the hardest of situations \& also after facing multiple defeats. He was defeated over seven times before finally being elected to President of the United States. While he did have some success in between those defeats, it is clear that had Lincoln given up earlier in his career, this nation as we know it may very well not even exist today

\section{Nelson Mandela - Strive To Be Better, Not Bitter}

"Do not judge me by my successes, judge me by how many times I fell down and got back up again."

- Nelson Mandela

Nelson Mandela was born on July 18, 1918, in Mveso, Transkei, South Africa. Becoming actively involved in the anti-apartheid movement in his 20s, Mandela joined the African National Congress in 1942. For 20 years, he directed a campaign of peaceful, non-violent defiance against the South African government and its racist policies. In 1993, Mandela and South African President F.W. de Klerk were jointly awarded the Nobel Peace Prize for their efforts to dismantle the country's apartheid system. In 1994, Mandela was inaugurated as South Africa's first black president.

Nelson Mandela is the impersonation of this powerful lesson. He was put in jail by a brutal regime for 27 years simply because he was fighting for fairness and equality. But even while jailed, he continued to be a leader and the symbol of the struggles of South Africans. Amazingly, after his release from jail, he became a stronger leader, not bitter or ready for revenge. He found common ground, embracing those who were once against him and helping the country bridge a seemingly impossible gap.

\section{Julius Caesar - Learning From Experience}

"Experience is the teacher of all things."

- In the words of Shakespeare's Caesar

Allegedly the descendent of Trojan prince Aeneas, Julius Caesar's auspicious birth c. July 12 or 13, 100 B.C., marked the beginning of a new chapter in Roman history. By 31, Caesar had fought in several wars and become involved in Roman politics. After several alliances, he became dictator of the Roman Empire. This led to a senatorial coup, and Caesar's eventual assassination, on the Ides of March.

Julius Caesar had years of experience fighting with the legionnaires. He didn't learn to be a great military leader from a philosopher or a book, but from hard experience. And he didn't merely live the experience without learning the lessons and taking stock. Many people go through long years of powerful experiences and walk away none the wiser. It is important to take time to reflect and learn from your experience.

Julius Caesar learned soldiering with the rank and file of the Roman legions. He fought in the front lines, shoulder to shoulder with legionnaires. He slept with them, ate with them, drank with them, marched with them and bled with them. Had he not spent years in the trenches doing the work himself, he would not have been the military leader he became.

\section{Martin Luther - Embrace Your Fear}

"If you are not anxious, that means you are not engaged, that you shouldn't fear fear, you should go with it" - Martin Luther

Martin Luther King Jr. was one of America's most influential civil rights activists. His passionate, but non violent protests, helped to raise awareness of racial inequalities in America, leading to significant political change. Martin Luther King Jr. was born on January 15, 1929, in Atlanta, Georgia. Through his activism, he played a pivotal role in ending the legal segregation of African-American citizens in the South and other areas of the nation, as well as the creation of the Civil Rights Act of 1964 and the Voting Rights Act of 1965. King received the Nobel Peace Prize in 1964, among several other honors. King was assassinated in April 1968, and continues to be remembered as one of the most lauded African-American leaders in history, often referenced by his 1963 speech, "I Have a Dream."

King didn't hide his fear. He was scared before every speech and worried that his points wouldn't be well received or that he would be met with violent protests, says Smith. But instead of hiding, he talked about it and faced his fear head on. King's willingness to embrace his fear is a great lesson for small business owners. Organizations may fear competition and new technology in today's business environment, but instead of shying away it is important to face these obstacles head on and not to be afraid of change. 


\section{Conclusion}

"If history were taught in the form of stories, it would never be forgotten."

- Rudyard Kipling

Throughout history there are certain figures that stand out as naturally great leaders. It is always useful for managers to focus on the qualities that made these people great and try to emulate them. In today's ultracompetitive business world, executives are pressured to deploy all the weapons in their arsenals to stay ahead of the opposition and win the day. The need to tap the wisdom and experience of some of history's greatest leaders is more today than ever before. The visionary leadership style of these extraordinary leaders is the classic mould of leadership currently taught in business schools \& military academies. Their leadership style can be considered the most effective of all styles because it communicates a sense of common purpose to people. A strong business case for this style can be made when looking at the retention of employees, pride in the organization, inspired and empowered employees, and a shared sense of goals and purpose.

\section{Books:}

\section{References}

[1]. Sharma, Robbin, Leadership Wisdom, Mumbai, Jaico Publishing House,2008.

Internet Sources :

[2]. http://thebrandbuilder.wordpress.com/2010/05/20/10-things-julius-caesar-could-have-taught-us-about-business-marketingleadership-and-even-social-media/

[3]. http://www.ynaija.com/opinion-five-leadership-lessons-from-martin-luther-king-jr/

[4]. http://www.ecsellinstitute.com/blog/bid/81492/5-Leadership-Lessons-from-Martin-Luther-King-Jr

[5]. http://managementnotes.blogspot.in/2011/07/7-leadership-lessons-from-alexander.html

[6]. http://www.guardian.co.uk/money/2010/mar/13/business-learn-great-leaders-history

[7]. http://au.ibtimes.com/articles/328948/20120417/leadership-10-great-leaders-history-ibtimesau-ibtimes.htm

[8]. http://www.scuttleyourship.com/historical-leaders.aspx

[9]. http://www.industryleadersmagazine.com/leadership-and-10-great-leaders-from-history/ 